\title{
Development of Objective Sozological Zoning in the Territory of the Republic of Adygea (as Exemplified by Invertebrates)
}

\author{
Alexandr Zamotajlov*, Maksim Shapovalov, Maksim Saprykin and Tatyana Varshanina \\ Adyghe State University (AGU), 385000, Maikop, Street Pervomayskaya, 208, Russian Federation; \\ gic-info@yandex.ru
}

\begin{abstract}
Based on the analysis of the habitat of 160 invertebrate species included in the Red Book of the Republic of Adygea (2012), we provided preliminary sozological zoning of the territory of the republic and identified areas that are promising as natural areas of protection. With account of the approaches provided in the article, we find it promising to revise the republican "system" of regional and local (municipal) SPNR, preserving the existing and establishing new ones, which fit into the potential ecological framework of the region.
\end{abstract}

Keywords: Fauna, Invertebrate Animals, Nature Reserves, Monuments of Nature, Red Book, Republic of Adygea, Special Protected Natural Areas (SPNR), Sozological Zoning, the Caucasus Reserve, the Concept of a "Marker Taxon"

\section{Introduction}

The regions of the North Caucasus are of high biological diversity at all levels of its manifestation: taxonomy, ecosystem, and landscape ${ }^{1}$. Here with, the systems of organisms, especially invertebrates, experience today a negative impact in changing environmental cconditions?. These facts demand adequate reaction from both the administrative structures commissioned to protect the environment, and the researchers dealing with the problem. The most important element of this work is to identify areas containing legally protected forms of life, and to assess their role in maintaining regional biodiversity.

The Republic of Adygea has an area of 7,800 sq.km and stretches for $165 \mathrm{~km}$ from west to east, and for $208 \mathrm{~km}$ from north to south. It is characterized by a considerable variety of natural-climatic conditions. The Republic occupies a part of the Trans-Kuban plain and the Caucasus Mountains, consisting mainly of foothill cuesta ridges (wooded, pastoral, and rocky) and higher mountain elevations (generally located in the south), conventionally divided into lowlands, midlands, and highlands. Thus, the republic occupies the central part of the natural region called Northwest Caucasus ${ }^{4}$.

According to the scheme of territorial planning of the Republic of Adygea, there are 34 specially protected natural areas (hereinafter - SPNR) of different statuses and categories in the region. Just areal SPNR of federal importance occupy 91,530 hectares. By decision of public authorities of the Russian Federation or the Republic of Adygea, they have been fully or partially withdrawn from economic use, and a special protection mode has been established for them. Here with, the republic holds a leading position among the federation subjects by the relative area of SPNR, which is about $30 \%$ of the entire territory. In addition, Adygea hosts a World Heritage Site-Western Caucasus (approved on November 30, 1999 at the $23^{\text {rd }}$ session of the World Heritage Committee), which also assumes significant limitation of any economic activity.

Obviously, in this situation, the justification of the eligibility of the existence of the effective protected areas or approaches to optimization of the republican network

\footnotetext{
* Author for correspondence
} 
of SPNR must be based on a scientific approach. The methodology of such an analysis has been proposed previously by A. S. Zamotailov and V. I. Shchurov ${ }^{8,9}$. Briefly, it involves the selection of areas with the maximum spatial concentration of legislatively protected taxa of different taxonomic groups and their critical habitats. The first stage of this work provides for the registration of regional ranges of protected organisms using graticule and visual assessment of the existing matches ${ }^{7}$. Further work will require specification of the regional areas and the use of numerical methods to assess the sozological significance of the individual elements of the territories ${ }^{9-11}$. In this respect, the use of the Multipurpose National Geographic Information System of the Republic of Adygea ${ }^{6}$, which has been already established in the Adyghe State University with its subsequent modification to fit the goals of the work, is promising.

This publication illustrates the prospects for the implementation of the approach indicated by the example of invertebrates in the Republic of Adygea. The purpose of the study is to find out the spatial distribution of the protected invertebrate species, reliable identification of areas with the highest concentration of their critical habitat, as well as correlation of the data obtained with the location of the SPNR of the Republic of Adygea.

\section{Material and Methods}

The basis of the analysis is the official mapping information for the Republic of Adygea ${ }^{2,3}$. To register the regional area, we used the scheme applied in the species essays of the Red Book of the Republic of Adygea (2012), which is a map of the region divided into squares using the Gauss-Krüger coordinate system (Figure 1). The unit of the species habitat indication is square (10 sq. $\mathrm{km}$ in size). Even in the case of "point" habitats, the square is filled completely, both in and beyond the territory of Adygea. To fill the plots of the regional area, we used two colors: the blue color indicates the found taxon within the territory bounded by the grid square (or part thereof) within Adygea; the red one shows the presence of the critical habitat of a taxon within this territory (Figure 2). The map also reflects the spread of animal taxa outside Adygea, which, regardless of the status of their populations in the neighboring regions of the Russian Federation, was reflected by filling the corresponding square (or part thereof) with green color within the map.
We performed superposition of habitats of the protected species and analyzed the spread of 160 species of invertebrates.

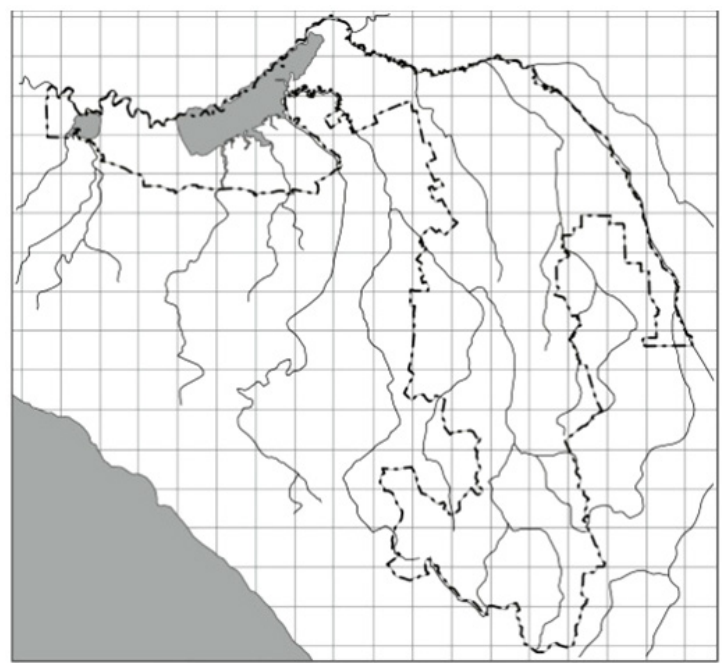

Figure 1. The blank form for registration of the habitat of protected animals in the Republic of Adygea and adjacent territories.

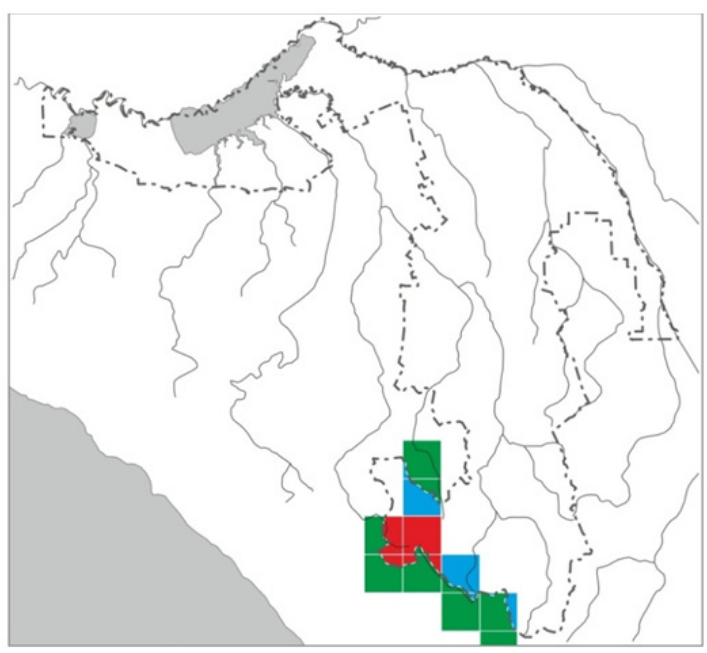

Figure 2. Sample illustration of the habitat of a taxon in the red book of the Republic of Adygea (2012).

To assess the sozological significance of each square, we accepted gradation of 8 ranges of abundance of the legally protected invertebrate animals (Figure 4 ).

\section{Results and Discussion}

For many taxonomic groups of animals included in the Republican Red Book (2012), the "marker taxon" concept 
is used, according to which in order to save the whole ecological system of species (or vice versa, sympatric taxa), indicator species are to be selected from one environmental group (local cenofauna) and included in the Red Book ${ }^{5}$. It is assumed that the preservation of habitats of their populations provides protection of the entire group of ecologically or topically related species. Thus, it is possible to avoid overloading the publication and the legislative framework by numerous species of invertebrates. Therefore, this analysis does not actually affect all species potentially needing special measures of protection.

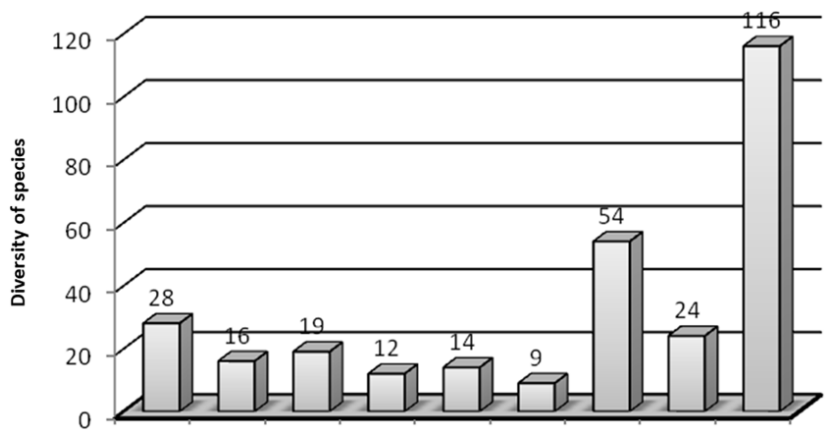

Figure 3. Diversity of the Protected Species of Invertebrates in the Administrative Regions of Adygea: Tak - Takhtamukaiskii, Teuch - Teuchezhskii, Kras Krasnogvardeiskii, Shov - Shovgenovskii, Giag - Giaginskii, Kosh - Koshekhablskii, Mayk_r - Maikopskii (Flat Side) Mayk_pg - Maikopskii (Foothills), Mayk_g - Maikopskii (Mountain Side).

A marker taxon is commonly understood as a stenotopic taxon that is widely distributed in a biotope typical of it, a readily identifiable and observable species selected from a group of rare, endemic species of the same rank within a single order (family), similar by ecological preferences and biotopical confinedness, the state of the local populations of which correlates with the degree of anthropic transformation of the habitats populated by it. Indicators of the state (population, density, area, and habitat fragmentation, the number and square of habitats) of the populations of a marker taxon are admitted as the indicators of the state of the members of one order (family) living together with it and relating to the same environmental group. A marker taxon must also comply with the regional Red Book categories, i.e. the threat of extinction of its population (according to the provisions of the IUCN) should be sufficiently realistic.

An analysis of the reasons for declining populations of rare species and the disappearance of the occupied habitats by these processes are still in the relatively early stages of the ecosystem degradation, when changes are reversible, and many practically used properties of natural communities has not been lost ${ }^{9}$. Thus, the poor state of the rare species of living organisms can be used for early diagnosis of the ecological balance disorder.

Creating networks of protected areas requires comprehensive knowledge of the region and should be shaped as a specific scientific and methodical approach with developing a system of criteria. At present, Russia has not yet developed a methodology of creating an ecological network of SPNR. While the need to take into account the criteria for the designation of protected areas seems obvious, in practice, we face subjectivity in the approaches to their identification. Creating a representative system of specially protected natural areas is one of the most important lines of environment optimization.

True sozological zoning of the Republic of Adygea assumes the allocation of plots with a high variety of model groups of biota (protected species of invertebrates), as well as the presence of the habitat significant for them, and the high degree of their vulnerability to economic, recreational, and other human activities.

The Red Book of the Republic of Adygea (2012) included 160 species of invertebrates, of which insects

Table 1. Taxonomic structure of the protected species of invertebrates in Adygea

\begin{tabular}{lcccccc}
\hline Macrotaxon & \multicolumn{6}{c}{ Category in the Red Book of the Republic of Adygea $^{*}$} \\
\cline { 2 - 7 } & 0 & 1, I & 2 , UV & 3, RD & 4, NI & 5, SK \\
\hline Annelida & - & - & - & 1 & 1 & - \\
Mollusca & - & 2 & 6 & - & - & - \\
Arachnidae & - & - & - & - & 1 & - \\
Crustacea & - & - & 1 & - & - & - \\
Insecta & - & 23 & 52 & 47 & 19 & 7 \\
\hline \multicolumn{1}{c}{ Total: } & - & 25 & 59 & 48 & 21 & 7 \\
\hline
\end{tabular}

Remark: ${ }^{*}$ Categories of rarity are given as per the Red Book of the Republic of Adygea (2012) 
make up the vast majority (93\%) (Table 1 ). To evaluate the diversification of the regional fauna under protection, we analyzed the distribution of the protected species of invertebrates by administrative districts of Adygea (Figure 3). The ultimate species diversity was observed in the mountainous part of the Maikop district of the Republic. A slightly less number of species is known to inhabit the flat part of the Maikop district (54 species). Obviously, this distribution reflects the diversity of the natural landscapes and the level of biocenoses' disturbance.

The majority of the protected invertebrates were classified as sozologically "highly significant" categories of endangered and vulnerable species ( 84 species); 48 species are rare; and 21 species have been insufficiently studied. 7 species were included in the Republican Red Book by the vertical principle-they are "specially controlled."

The distribution of territories of the Republic of Adygea by sozological significance (as exemplified by invertebrates) is shown in Figure 4.

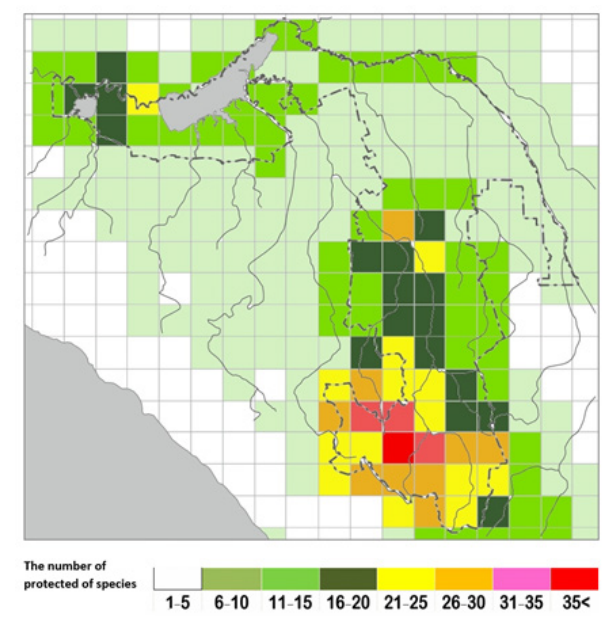

Figure 4. Zoning Map of the Territory of the Republic of Adygea by Sozological Significance (as Exemplified by Invertebrates).

As follows from the figure, only one square was marked in Adygea, which hosts more than 35 species of protected invertebrates. Herewith, only a small portion of the square lies within the territory of the Caucasian Nature Reserve. The number of squares accommodating from 26 to 35 species is small (12). An overwhelming number of the squares marked by sozological significance (77) accommodates between 6 and 15 species of protected invertebrates.

The vast majority of squares highly significant in terms of sozology are located in the south of Adygea, in the lowland and highland areas. They are only partly overlapped by the existing SPNR, first of all, by the Caucasus State Biosphere Reserve (Fig. 5). In the future, a more detailed analysis of the habitat of protected taxa is required to formulate proposals on borders of the actively developing recreational facilities.

The system of SPNR in the Republic of Adygea mainly formed around the core-the Caucasian State Nature Biosphere Reserve. The majority of the largest (82\% of all SPNR areas) and most valuable reserves of Adygea are concentrated in the southern, mountainous part of the republic, where, thanks to the common boundaries, they form a protected area. Those are the North Division of the Caucasian Reserve, the Natural Park "Bolshoi Tkhach," the monuments of nature "Verkhovia rek Pshekha and Pshekhashkha," "Khrebet Buinyi," and others. Another, much smaller part of SPNR is not functionally related to the nature reserve and is a point geographically disparate objects: reserves and natural monuments singled out mostly based on the recreational value, excluding sozological zoning of the republic's territory.

On the territory of the Caucasus Nature Reserve (CSNBR), the populations of threatened species of invertebrates included in the regional and federal Red Book are passively preserved. The set of the limiting factors in the territory of CSNBR, particularly those affecting the condition of invertebrates, is limited. The stable existence of the reserve is the guarantor of the survival of regional populations of more than 30 protected species of invertebrates.

State Nature Reserves (SNR) existing in Adygea, unlike other SPNR, have a functional specialization depending on the nature of the object to be conserved. For the purposes of the protection of threatened species of invertebrates, the complex, biological (botanical and zoological), and hydrological reserves are most suitable. Geological reserves, for example, can contribute to the conservation of populations of troglofauna and petrophytic and endogeic invertebrates. The existing practice of SNR organization in the territory of Adygea and the Krasnodar Region does not involve any special measures of direct protection of invertebrates, or suitable habitats for them in the territories of the existing reserves. No species of invertebrates, protected at both the regional and federal levels, are included in the list of special protection objects in the territory of the Adyghe SNR, despite the fact that they live here.

A similar pattern is typical of natural monumentsnone of the SNR certificates available for studying mentions any the rare species of invertebrates. It is despite 
the fact that this category of SPNR in Adygea is the most numerous one (more than 25 objects).

The protection of invertebrate animals in the region is the best to arrange in the state nature reserve, natural parks, state nature preserves, and natural monuments. However, though the special protection mode in CSNBR implies protection of all species of invertebrates, in other types of SPNR such protection cannot be carried out. Target protection of invertebrates may not be included in the provisions of a particular state preserve or the certificate of a particular natural monument.

It should be noted in the Republic of Adygea, the presence of highly sozologically significant areas was revealed, which do not relate to other SPNR existing in the region. Some of them, such as the one near the town of Maikop, and the Takhtamukaiskii and Teuchezhskii Districts experience the most intensive human pressure. The existing SPNR in the mountainous region only partially coincide with the dedicated sozologically significant areas. The ones near the town of Maikop do not cover the singled out squares, and in the appropriate boxes in the Takhtamukaiskii and Teuchezhskii Districts do not exist at all. Organization of local SPNR in the steppe zone of Adygea is needed.

Despite the fact that a large part of the republic lies in the most transformed steppe zone and the degree of insularization of the steppe cenoses is the highest, the major part of the protected species of invertebrates dwell exactly in these areas, in the steppe zone of the territory, in which the necessary legal protection of fauna has not been organized. Thus in Adygea, the skeleton structure of the system of SPNR covering all the variety of landscapes has not been formed. The structure of the stabilized landscape should be a form of environmentally related clusters, each of which includes a constant reserve area and territories of forest, agricultural, and recreational use, environmentally related to the reserve area.

Obviously, the improvement of the republican system of SPNR should be based on a reasonable compromise of natural resource users and conservation organizations. An important result of the analysis provided is the need to revise the republican "system" of regional and local (municipal) SPNR, preserving the existing and establishing new ones, which fit into the potential ecological framework of the region. In addition, in Adygea, there is an insufficient number of landscape reserves, integrated and landscape monuments of nature, which would be included in the system of ecological corridors. This would allow developing effective principles of conservation of the biological diversity and a strategy of development of territories and their sustainable environmental management.

There is a need for early development of a detailed geoinformation system for the protected objects of fauna and flora of Adygea, which will allow to integrate the protected areas into the existing economic infrastructure. To save the major part of species of plants and invertebrates, no organization of large area SPNR is necessary-the most promising option, obviously, is to create small cluster SPNR.

\section{Acknowledgment}

The authors express their sincere gratitude to the administration of the Adyghe State University and the Research Institute for Comprehensive Problems of the ASU for their assistance in the organization of the research, as well as the Office for Environmental Protection, Natural Resources, and Emergency Situations of the Republic of Adygea for their support of our work.

\section{References}

1. Abdurakhmanov GM. Aktual'nost' problemy sokhraneniia dikoi zhivoi prirody Severnogo Kavkaza, perspektivy ikh okhrany, uvelicheniia chislennosti i vosproizvodstvaю. Proceeding of the Biodiversity of the Caucasus and the South of Russia; XIV Mezhdunarodnaia nauchnaia konferentsiia; Makhachkala: IPA RD; 2012. p. 7-10.

2. Atlas Respubliki Adygeia. Maikop: ASU; 2005. p. 79.

3. Buzarov AS, Varshanina TP, Melnikova TN et al. Geografiia Respubliki Adygeia. Maikop: Adyghe Publishing House; 2001.

4. Kanonnikov AM. Priroda Kubani i Prichernomor'ia. Krasnodar: Krasnodarskoe knizhnoe izdatel'stvo; 1977.

5. Mnatsekanov RA, Zamotaylov AS, Schurov VI, editor. Krasnaia kniga Respubliki Adygeia. Redkie i nakhodiashchiesia pod ugrozoi ischeznoveniia ob"ekty zhivotnogo i rastitel'nogo mira. In two volumes. Part 1 . Vvedenie. Rasteniia i griby. $2^{\text {nd }}$ ed. Maikop: Kachestvo; 2012.

6. Khunagov RD, Varshanina TP. Mnogotselevaia Natsional'naia Geoinformatsionnaia sistema Respubliki Adygeia. Vestnik Adygeiskogo gosudarstvennogo universiteta. 2006; 1:253-9.

7. Shapovalov MI, Zamotailov AS. Otsenka regional'nogo sozologicheskogo statusa redkikh i ischezaiushchikh vidov zhivotnykh Severnogo Kavkaza (printsipy otbora vidov 
i registratsii regional'nykh arealov). Tr. KubGAU. 2013; 2(41):86-91.

8. Shchurov VI, Zamotaylov AS. Regional'nye arealy okhraniaemykh nasekomykh (Arthropoda, Insecta) Krasnodarskogo kraia i nedostatki «seti» okhraniaemykh territorii. Nauka Kubani, 2008; Annex: 61-7.

9. Shchurov VI, Zamotailov AS, Mnatsekanov RA, Skvortsov MM. Organizatsiia monitoringa ob"ektov Krasnoi knigi Krasnodarskogo kraia, vizualizatsiia i prakticheskoe primenenie ego rezul'tatov. Rezul'taty monitoringa vidov rastenii, zhivotnykh i gribov, zanesennykh v Krasnuiu knigu Krasnodarskogo kraia (2007-2011). Administration of the Krasnodar Region. Schurov VI (Resp. Ed.), Zamotailov AS,
Shchurov VI, Mnatsekanov RA (Sci. Eds.). Izhevsk: Publishing House University; 2012.

10. Zamotailov AS. Opyt organizatsii regional'noi i federal'noi okhrany ugrozhaemykh vidov nasekomykh Severo-Zapadnogo Kavkaza [Experience in organizing regional and federal protection of endangered species of insects in Northwest Caucasus]. VIII z'izd GO "Ukraïnske entomologichne tovaristvo”; 2013 serpnya 26 - 30. Kiïv: Vidavnichy Center NUBiP Ukraïni, 2013. p. 52-3.

11. Zamotailov AS (Ed.). Krasnaia kniga Respubliki Adygeia. Redkie i nakhodiashchiesia pod ugrozoi ischeznoveniia ob"ekty zhivotnogo i rastitel'nogo mira. Part 2: Zhivotnye. Second edition. Maikop: Kachestvo; 2012. 